\title{
Prognostic factors for cesarean section outcome of pregnant women with gestational diabetes mellitus: a systematic review and meta-analysis
}

This article was published in the following Dove Press journal:

Diabetes, Metabolic Syndrome and Obesity: Targets and Therapy

\author{
Jinjing Wang ${ }^{1,2, *}$ \\ Kang Chen ${ }^{1} *$ \\ Xinye Jin' \\ Xueqiong $\mathrm{Li}^{3}$ \\ Ping An' \\ Nan Yang ${ }^{4}$ \\ Yaolong Chen ${ }^{4}$ \\ Yi Fang ${ }^{2}$ \\ Yiming Mu' \\ 'Department of Endocrinology, Chinese \\ PLA General Hospital, Beijing 100853 , \\ People's Republic of China; ${ }^{2}$ Department \\ of Endocrinology, Fifth Medical Center of \\ PLA General Hospital, Beijing 10007I, \\ People's Republic of China; ${ }^{3}$ Department \\ of Gerontology, First Affiliated Hospital \\ of Kunming Medical University, Kunming \\ 65003I, People's Republic of China; \\ ${ }^{4}$ Evidence-Based Medicine Center, School \\ of Basic Medical Sciences, Lanzhou \\ University, Lanzhou, 730000, People's \\ Republic of China \\ *These authors contributed equally to \\ this work
}

Correspondence: Yiming Mu Department of Endocrinology, Chinese PLA General Hospital, No. 28, Fuxing Road, Haidian District, Beijing I00853,

People's Republic of China

Tel +86 I89 10968729

Email muyiming@30Ihospital.com.cn

Yi Fang

Department of Endocrinology, Fifth

Medical Center of PLA General Hospital,

Chinese PLA 307 Hospital, No. 8, East

Street, Fengtai District, Beijing 10007I,

People's Republic of China

Tel +86 I36 4I 223053

Email fangyi307@।63.com
Objective: To evaluate the prognostic factors for cesarean section outcome of pregnant women with diabetes mellitus.

Methods: MEDLINE, EMBASE, Cochrane Library, CBM, CNKI and Wanfang database were searched. Two researchers independently screened the literature, extracted data, and evaluated the risk of bias of included studies. For pooled data with factors of perioperative outcome, the RevMan software was used for data translation and meta-analysis. The result is shown intuitively with the bubble diagram of evidence mapping by Excel 2016.

Results: We included 12 randomized controlled trials (RCTs) in the meta-analysis. Twelve RCTs with 1,390 patients were included in the systematic review. The results show that the perioperative blood glucose management regimens, preoperative fasting and water deprivation, anesthesia regimens, postoperative fluid regimens, postoperative analgesia regimens, postoperative wound care regimens, psychological interventions, different dosing regimens for antibiotics, and obesity may affect the cesarean section outcome of diabetic mothers and newborns. The evidence for all the outcomes was low quality.

Conclusion: Many prognostic factors have shown significant association with postoperative outcomes of cesarean section. More clinical research evidence with high-quality is needed.

Keywords: gestational diabetes mellitus, caesarean section, prognostic factors, systematic review, meta-analysis, evidence mapping

\section{Background}

In pregnant women with gestational diabetes mellitus (GDM), the overall cesarean section rate was accounted for $35.3 \%$. ${ }^{1}$ Simultaneously, compared with nondiabetic pregnant women, diabetic maternal acute cesarean section rate was reported 1.52 times of GDM. ${ }^{2}$ Diabetes is an important risk factor for surgical incision infection, ${ }^{3}$ and for cesarean section, diabetes is an important risk factor for maternal postoperative wound infection as well. ${ }^{4}$ Thus, the pregnancy with diabetes and the management of special risk factors are important, and the existing systematic evaluation shows that effective treatment and control of GDM can reduce preeclampsia, shoulder dystocia, and the incidence of huge children. ${ }^{5}$ In addition, several systematic reviews have concentrated on the effects of certain specificc factors based on the health outcomes of pregnant women with GDM, such as the effects of different glycemic management regimens on glycemic control and maternal and child outcomes, ${ }^{6-10}$ and effects of dietary intervention or nutritional 
therapy based on maternal and child outcomes. ${ }^{11,12}$ For patients with cesarean section with GDM, there have been several studies evaluating differences in patients' outcomes under different conditions, such as anesthesia, ${ }^{13-15}$ postoperative fluid regimen, ${ }^{16,17}$ and postoperative wound care. ${ }^{18}$ However, there is no systematic review regarding the current evaluation of the factors affecting the maternal and child's outcomes during the period of affecting by GDM. This study was designed to assess the risk factors associated with perioperative outcomes in pregnant women with GDM.

\section{Methods}

\section{Inclusion and exclusion criteria}

Inclusion criteria: 1) pregnant women suffered cesarean section with GDM; 2) exposure factors for cesarean outcomes; 3) RCTs; and 4) reported perioperative outcomes, such as blood glucose level, Apgar scores, adverse effects, and so on. Exclusion criteria: 1) there were no specific outcome data to assess the impact of exposure factors on patients with perioperative outcomes; 2) nonEnglish and Chinese published research, 3) summary of unpublished meeting.

\section{Literature search}

We conducted a systematic search on Medline (via PubMed), EMBASE, Cochrane Library, CBM, CNKI and Wanfang, using the terms Diabetes, Gestational, Diabet*, "Cesarean Section", caesarean, "diabetes, pregnancy", "gestational diabetes mellitus", "cesarean section", "cesarean section", "caesarean section". The retrieval date was February 28, 2018.

\section{Study screening}

Two researchers independently screened the literature titles, abstracts, and the full text. A pre-test was performed prior to formal screening of the literature to ensure that each researcher truly perceived the screening criteria and process. Discrepancies between the two reviewers were resolved by consensus discussion.

\section{Data extraction}

The two researchers independently extracted the following data from the pre-designed information extraction table: year of publication, name of journal, the first author's affiliation, place and duration of study, funding, conflict of interest, type of study, sample size, basic characteristics of study object, exposure factors, and associated outcome data. A pretest was conducted before formal extraction to ensure that each researcher agrees with the extraction criteria and process. If there are some differences, they could be solved through discussion.

\section{Risk of bias assessment}

Two researchers used the Cochrane risk of bias tool was used for bias risk assessment of randomized controlled trials. A pretest was conducted before the formal evaluation to ensure that each researcher agrees with the evaluation criteria and process. In case of existence of some differences, they could be solved by a third researcher.

\section{Data consolidation and analysis}

In the RevMan 5.3 software, the RR and $95 \% \mathrm{CI}$ were used to combine the binary data, and the data were merged using the mean difference (MD) and $95 \%$ CI. The data combination uses a random-effect model. The heterogeneity was included in the study by Cochran's Q test $(P<0.05$ denotes heterogeneity) and $I^{2}$ test. When the number of inclusion indicators is $\geq 10$, the publication bias is evaluated by making a funnel plot; conversely, the qualitative analysis was included in the study funding, the conflict of interest, and the outcome to discuss the possibility of publication bias.

\section{Quality of evidence}

The quality of the evidence was graded according to the principles of the GRADE approach used in the evaluation of prognostic studies ${ }^{19,20}$ and in a previous study (as example). ${ }^{21}$ (These factors may lead to rating down the quality of evidence in GRADE system) and the three upgraded factors (large effect, dose-response, and plausible confounders) to determine the final level of evidence. Quality of evidence was ranked as high, medium, low, and very low-level using the results of summary table.

\section{Evidence mapping}

Excel 2016 was used to integrate the RR value from metaanalysis and GRADE. The result is shown intuitively with the bubble diagram. Due to heterogeneity of MD for the outcome, we did not make a bubble diagram for MD value from meta-analysis. 


\section{Results}

\section{Study selection}

There are 13,447 articles identified by literature search. After duplicates were removed in endnote, 11,585 records titles and abstractswere reviewed, 142 articles were retrieved full-text reviewing. Finally, a total of 12 randomized controlled trials ${ }^{14,16-18,22-29}$ involving 1,390 patients were included for meta-analysis (Figure 1).

\section{Characteristics of the included studies}

The studies were published in 2010 and 2017, the sample sizes ranged from 33 to 201. All studies were from China. The participant age was from 24 to 39. The two studies $^{16,23}$ were funded by nonprofit funds, one study reported that there was not the conflict of interest, and the rest of the study did not report funding (Table 1).

\section{Risk of bias for included studies}

The included RCTs were only low risk of bias in incomplete outcome data and selective reporting (Figure 2); 8 studies $^{14,17,18,24-26,29}$ did not report random sequences; 1 study ${ }^{27}$ reported that there was a high risk of bias in random sequences; none of the studies reported allocation concealment; 6 studies ${ }^{16,18,26-29}$ did not blind the researchers and patients, and they likely contained an impact on the results; 8 studies $^{14,18,22-26,29}$ did not blind the outcome evaluators, and they likely contained an influence on the results.

\section{Prognostic factors Insulin pump}

One randomized controlled study ${ }^{25}$ reported a total of 3 outcomes. It was revealed that duration of treatment process ( $\mathrm{MD}=-5.30,95 \% \mathrm{CI}:-5.78 \sim-4.82, P<0.00001)$, insulin dosage $(\mathrm{MD}=17.00,95 \% \mathrm{CI}:-23.04 \sim-10.96$, $P<0.00001$ ), and the incision healing duration ( $\mathrm{MD}=$ $-4.40,95 \%$ CI: $-5.58 \sim-3.22, P<0.00001)$ of the repeated subcutaneous injection for insulin group were superior to those of the insulin pump group, and the difference was statistically significant (Appendix 1).

\section{Short-term fasting and water deprivation}

One randomized controlled study ${ }^{27}$ reported a total of 11 outcomes. Preoperative blood glucose concentrations

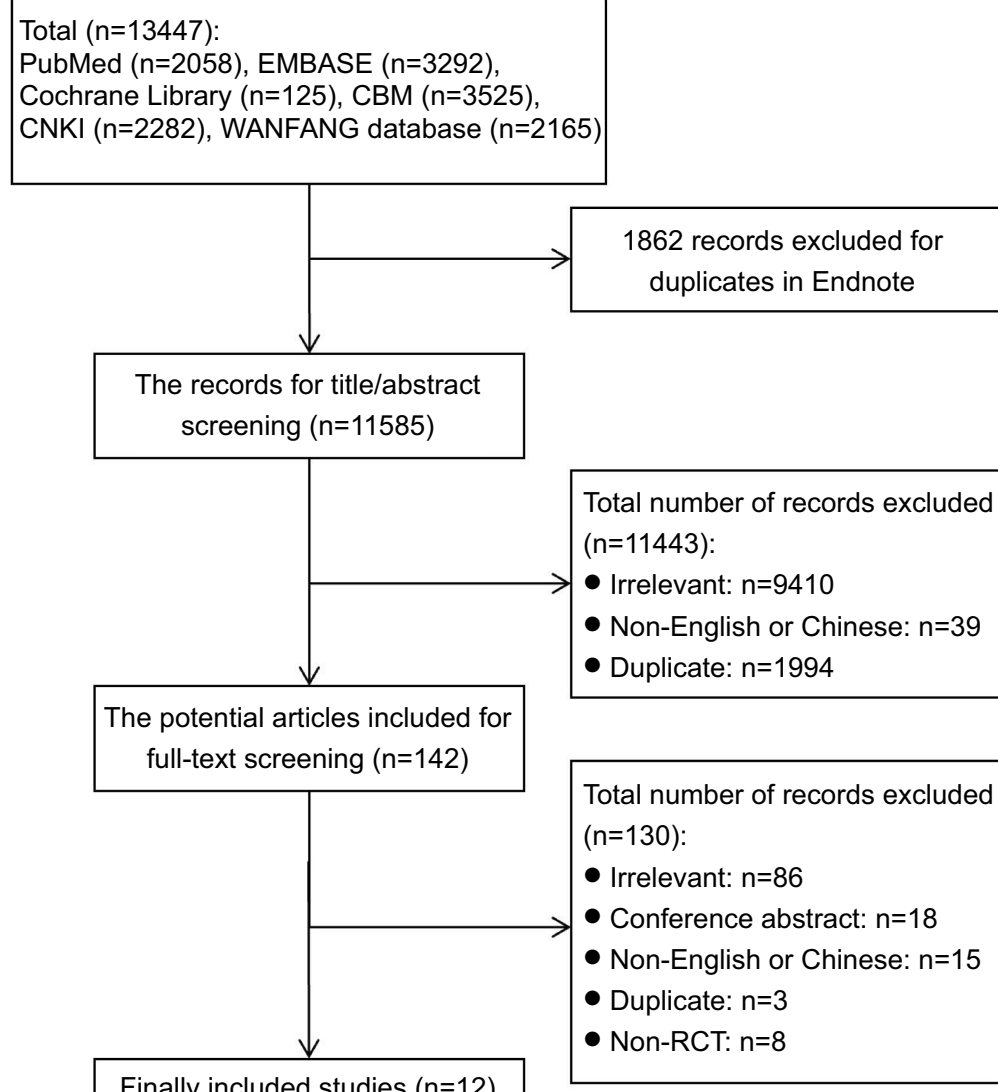

Finally included studies $(n=12)$

Figure I The screening flow chart. 


\begin{tabular}{|c|c|c|c|c|c|c|c|c|c|c|c|c|c|}
\hline \multirow{3}{*}{ 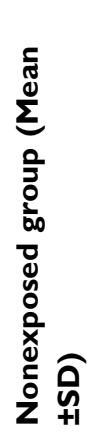 } & 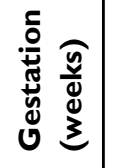 & $\circ$ & 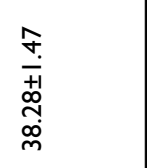 & $\circ$ & $\circ$ & $\circ$ & $\begin{array}{l}\sigma \\
\frac{\sigma}{+1} \\
\infty \\
\infty \\
\infty \\
\infty\end{array}$ & $\circ$ & 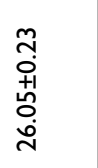 & $\circ$ & 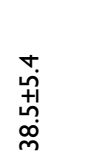 & $\begin{array}{l}\dot{a} \\
\dot{+} \\
\frac{+1}{\infty} \\
\dot{m}\end{array}$ & $\circ$ \\
\hline & 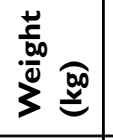 & $\circ$ & $\circ$ & $\circ$ & $\circ$ & $\begin{array}{l}\text { No } \\
\text { +1 } \\
\text { N }\end{array}$ & $\circ$ & $\circ$ & $\circ$ & $\circ$ & $\circ$ & $\begin{array}{l}m \\
\stackrel{m}{+1} \\
\stackrel{+1}{R}\end{array}$ & $\circ$ \\
\hline & $\underset{8}{8}$ & 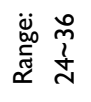 & 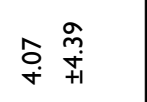 & $\circ$ & $\circ$ & $\overline{\dot{m}} \overline{\dot{+}}$ & 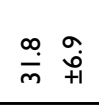 & 守 & 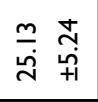 & 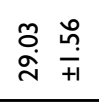 & 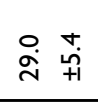 & స̃. & 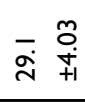 \\
\hline \multirow{3}{*}{ 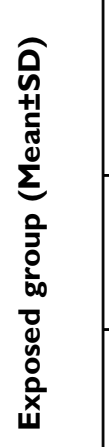 } & 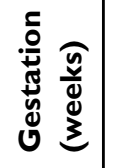 & $\circ$ & 草 & $\circ$ & $\circ$ & $\circ$ & 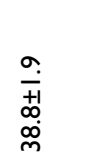 & $\circ$ & 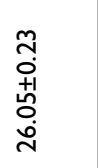 & $\circ$ & 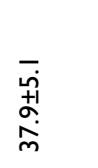 & 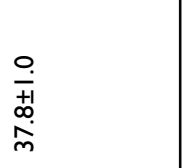 & $\circ$ \\
\hline & 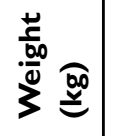 & $\circ$ & $\circ$ & $\circ$ & $\circ$ & $\begin{array}{l}m \\
0 \\
+1 \\
+1 \\
i \\
i\end{array}$ & $\circ$ & $\circ$ & $\circ$ & $\circ$ & $\circ$ & 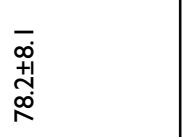 & $\circ$ \\
\hline & $\stackrel{8}{8}$ & 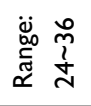 & 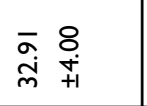 & $\circ$ & $\circ$ & $\hat{i} \hat{i}$ & 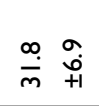 & $\begin{array}{l}\stackrel{+}{*} \\
\stackrel{N}{*}\end{array}$ & 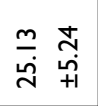 & 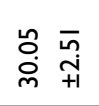 & 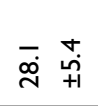 & $\hat{\dot{m}} \bar{i}$ & 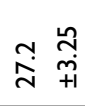 \\
\hline \multicolumn{2}{|l|}{ 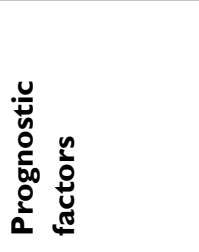 } & 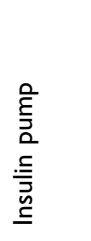 & 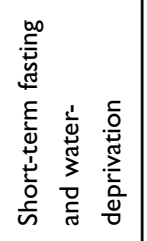 & 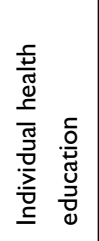 & 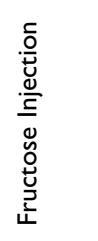 & 㟧 & 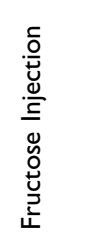 & 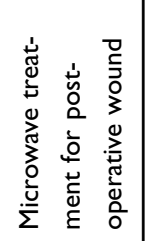 & 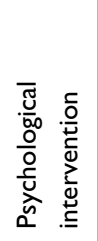 & 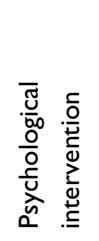 & 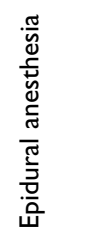 & 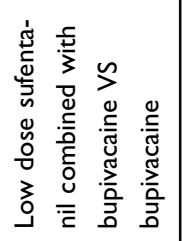 & 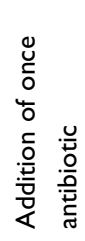 \\
\hline \multicolumn{2}{|l|}{$\begin{array}{l}\frac{0}{0} \\
\text { जू } \\
\text { जू }\end{array}$} & $\stackrel{\infty}{+}$ & $\underline{\underline{\Xi}}$ & 으 & ㅇ & $m$ & $\bar{i}$ & q & $\underline{\underline{n}}$ & ষ্ণ & Lे & ฉ & 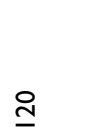 \\
\hline \multicolumn{2}{|l|}{ 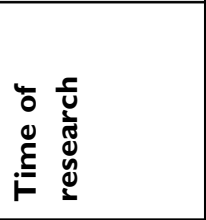 } & 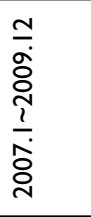 & 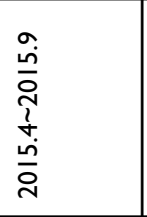 & 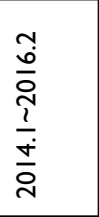 & 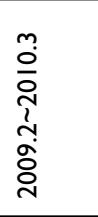 & 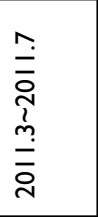 & 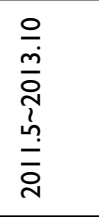 & 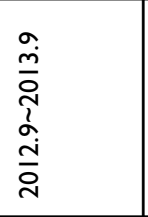 & 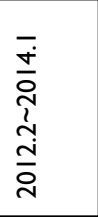 & $\begin{array}{l}\frac{n}{n} \\
\stackrel{n}{2} \\
\frac{i}{\dot{T}} \\
\frac{i}{2}\end{array}$ & 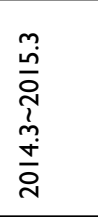 & $\begin{array}{l}\stackrel{N}{c} \\
\bar{m} \\
\stackrel{i}{2} \\
m \\
\stackrel{\sim}{o}\end{array}$ & 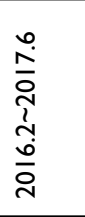 \\
\hline \multicolumn{2}{|c|}{ 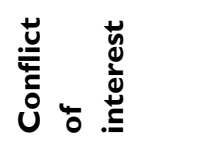 } & $\circ$ & $\circ$ & $\circ$ & $\circ$ & $\circ$ & $\circ$ & $\circ$ & $\circ$ & $\circ$ & $\circ$ & $\circ$ & $\circ$ \\
\hline \multicolumn{2}{|l|}{ 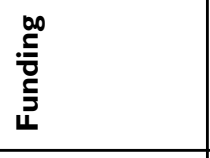 } & $\circ$ & $\circ$ & $\circ$ & ๘ & $\circ$ & $\circ$ & $\circ$ & $\circ$ & $\bullet$ & $\circ$ & $\circ$ & $\circ$ \\
\hline \multicolumn{2}{|l|}{ 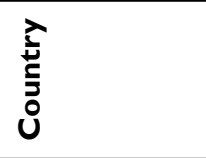 } & 苞 & 莺 & 妾 & 妾 & 妾 & : & : & 胥 & 妾 & 莺 & 胥 & 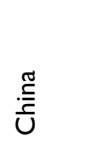 \\
\hline \multirow[t]{2}{*}{ ঠँ } & & 음 & $\hat{\bar{n}}$ & ì & $\frac{0}{2}$ & $\overline{\bar{n}}$ & $\stackrel{\nabla}{\circ}$ & $\frac{n}{2}$ & $\frac{n}{2}$ & $\frac{n}{2}$ & $\frac{n}{2}$ & $\frac{n}{2}$ & 홍 \\
\hline & & 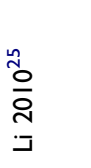 & 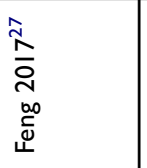 & 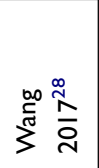 & 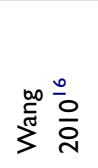 & $\stackrel{\stackrel{ \pm}{N}}{\frac{\pi}{N}}$ & 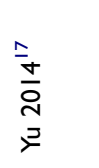 & 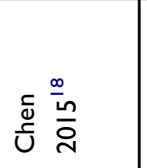 & 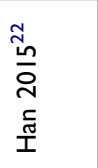 & $\begin{array}{l}\stackrel{\widetilde{n}}{\stackrel{n}{a}} \\
\stackrel{\Xi}{\Xi}\end{array}$ & $\begin{array}{l}\stackrel{ \pm}{n} \\
\stackrel{n}{\circ} \\
\stackrel{5}{\succ}\end{array}$ & 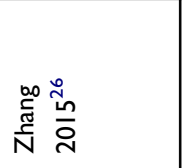 & 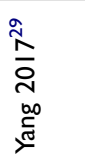 \\
\hline
\end{tabular}




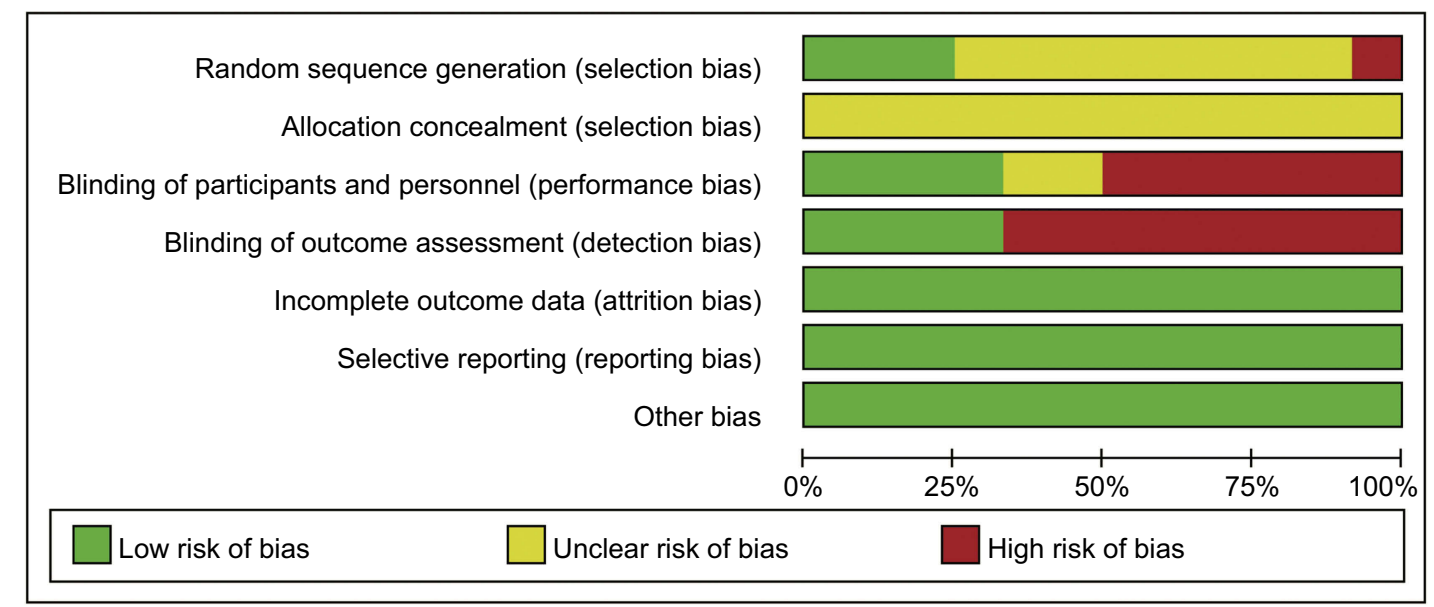

Figure 2 Risk of bias graph.

(MD=0.84, 95\% CI: $0.42 \sim 1.26, P=0.001)$ and the level of blood glucose in newborn infants after birth $(\mathrm{MD}=0.45$, 95\% CI: $-0.03 \sim 0.87, P=0.038$ ) for short-term group were superior to those of long-term group, and the difference was statistically significant. Bleeding volume during cesarean section $(\mathrm{MD}=-42.71, \quad 95 \% \quad \mathrm{CI}:-82.55 \sim-2.86$, $P=0.039$ ) for short-term group was inferior to long-term group, and the difference was statistically significant. There were no significant differences in postoperative blood sugar concentrations, the rates of nausea and vomiting, incidence of hypoglycemia in newborn infants after birth and mothers before cesarean section, duration of anus exhausting of puerpera, Apgar score 1 and 5 mins after delivery (Appendix 1).

\section{Individual health education}

A randomized controlled study ${ }^{28}$ reported a total of 4 outcomes. Control rates for $2 \mathrm{hr}$ plasma glucose (PG) (RR=1.31, 95\% CI: 1.04 1.66, $P<0.05)$ and midnight blood glucose $(\mathrm{RR}=1.23,95 \% \mathrm{CI}: 1.01 \sim 1.50, P<0.05)$ and the satisfaction rate of nursing services $(\mathrm{MD}=6.51$, 95\% CI: 5.80 7.22, $P<0.01$ ) for individualized health education group were superior to those of conventional health education group, and the difference was statistically significant. There were no significant differences in control rates of fasting blood glucose (FBG) as well (Appendix 1).

\section{Fructose injection}

Two randomized controlled trials ${ }^{16,17}$ reported a total of 8 outcomes. The blood glucose levels 1.5-2 hours after infusion $(\mathrm{MD}=-1.17,95 \% \mathrm{CI}:-1.93 \sim 0.41, P=0.003)$, blood glucose levels $3-4$ hours after infusion $(\mathrm{MD}=-0.99,95 \% \mathrm{CI}$ : $-1.61-0.36, P=0.002)$, the level of insulin 1.5 hours after infusion $\quad(\mathrm{MD}=-13.50, \quad 95 \% \quad \mathrm{CI}: \quad-19.02 \sim 7.98)$ $(P<0.00001)$, and the level of insulin 3 hours after infusion $(\mathrm{MD}=-8.59,95 \% \mathrm{CI}:-13.75 \sim-3.43, P=0.001)$ for fructose injection were superior to glucose and Insulin injection. The difference was statistically significant. There were no significant differences in blood glucose level, blood glucose level, urinary carcass positive rate, and urine sugar positive rate after transfusion, and no significant difference was found between the two groups (Appendix 1).

\section{Patient-controlled epidural analgesia (PCEA)}

A randomized controlled trial ${ }^{24}$ reported a total of 13 outcomes. The level of blood glucose in presence of analgesia after 6 hours $(\mathrm{MD}=-0.80,95 \% \mathrm{CI}:-1.01$ to -0.59 , $P<0.00001)$, 12 hours $(\mathrm{MD}=-0.76,95 \% \mathrm{CI}:-1.00$ to $-0.52, P<0.00001), 24$ hours $(\mathrm{MD}=-0.65,95 \% \mathrm{CI}:-0.87$ to $-0.43, P<0.00001)$, and 36 hours $(\mathrm{MD}=-0.75,95 \% \mathrm{CI}$ : $-0.96 \sim 0.54, P<0.00001)$ for the patient-controlled intravenous analgesia (PCIA) group was superior to PCIA group. The difference was statistically significant. There was no significant difference between the two groups (Appendix 1).

\section{Microwave treatment for postoperative wound}

A randomized controlled trial ${ }^{18}$ reported a outcome (RR=1.15, 95\% CI: 1.03 1.29, $P=0.01$, see Appendix 1, in which the difference was statistically significant $(P<0.01)$ (Appendix 1).

\section{Psychological intervention (including music therapy)}

Two randomized controlled trials ${ }^{22,23}$ reported a total of 14 outcome indicators, in addition to entering the operating room immediately with heart rate $(\mathrm{MD}=-0.86,95 \%$ CI: $-2.69 \sim 0.97, P=0.36$ ), entering the operating room immediately with anxiety score $(\mathrm{MD}=-0.13,95 \%$ 
CI: $-2.57 \sim 2.31, P=0.92$ ), and the normal feeding rate $(\mathrm{RR}=1.07,95 \% \mathrm{CI}: 0.99-1.16, P=0.09)$. The difference between the two groups was not statistically significant. The rest of the outcome indicators for the psychological intervention group were inferior to the conventional nursing group, and the difference between the two groups was statistically significant (Appendix 1).

\section{Epidural anesthesia}

A randomized controlled trial ${ }^{14}$ reported a total of six outcomes: glucose concentration at the of cutting skin (MD=1.48, 95\% CI: 1.31 1.65, $P<0.00001,2$ hours after delivery ( $\mathrm{MD}=0.90,95 \% \mathrm{CI}: 0.71$ to $1.09, P<0.00001)$ and 6 hours after delivery $(\mathrm{MD}=1.11,95 \% \mathrm{CI}: 0.93$ to 1.29 , $P<0.00001$ ), the epidural group were higher than the general anesthesia group, and the difference was statistically significant. The differences in the other outcomes between the two groups were not statistically significant (Appendix 1).

\section{Low-dose sufentanil combined with bupivacaine of spinal-epidural anesthesia}

One randomized controlled study ${ }^{26}$ reported a total of 11 outcomes. Based on the report, glucose concentration at the time of cutting skin (MD=-1.45, 95\% CI: $-1.61 \sim 129$, $P<0.00001)$, the blood glucose concentration 2 hours after delivery ( $\mathrm{MD}=-0.89$, 95\% CI: $-1.07 \sim 071, P<0.00001)$, and the mean arterial pressure 5 mins after anesthesia ( $\mathrm{MD}=5.80,95 \%$ CI: 3.12 8.48, $P<0.00001)$ were assessed. The difference was statistically significant. However, the differences for the other outcome indicators between the two groups were not statistically significant (Appendix 1).

\section{Addition of once antibiotic}

One randomized controlled study ${ }^{29}$ reported a total of 12 outcomes. The treatment efficiency $(\mathrm{RR}=0.68,95 \% \mathrm{CI}$ : $0.04 \sim 1.66, P<0.05)$ of the addition of an antibiotic once group was inferior to 24 hours antibiotic application group, and the difference was statistically significant. There were no significant differences in response rate, overall response rate, the inefficiency rate, the duration of $\mathrm{WBC}<12 \times 10^{9} / \mathrm{L}$, body temperature (without fever or returned to normal status 2 hours after surgery), and the grades $\mathrm{A}, \mathrm{B}$, and $\mathrm{C}$ of healing (Appendix 1).

\section{Publication bias}

The number of studies included in every outcome was $<10$; thus, it was unattempted to use funnel plot to assess the publication bias. All studies have not reported conflict of interest, and only 2 studies reported that the funding originated from the nonprofit grants.

\section{Quality of evidence}

The levels of evidence for all the outcome all is low on the GRADE system (see Appendix 2). The reasons for downgrading includes the risk of bias (no randomized sequence generation and allocation concealment, no blindness to researchers, patients and outcome evaluators) and inaccuracy (sample size is less than the optimal sample size and the confidence interval of the combined results cross invalid line).

\section{Evidence mapping}

Each bubble corresponds to one outcome for the prognostic factors. The size, color, and position of the bubbles were used to indicate the current research status. The size of the bubbles indicates the sample size, and the color of the bubbles indicates the quality of the evidence. The horizontal coordinate indicates the prognostic factors, the vertical coordinate indicates the RR of meta-analysis (Figure 3).

\section{Discussion}

The International Federation of Gynecology and Obstetrics (FIGO) guideline recommended to receive cesarean section to prevent shoulder dystocia or birth injury, when fetal weight would be $>4,000$ g. ${ }^{30}$ For pregnant women with cesarean section, in addition to the conventional perinatal management, the integration of perioperative management is required, including blood sugar control, anesthesia, healthcare, etc. This study is the first systematic review of the prognostic factors. The results of the systematic review show that the perioperative blood glucose management regimens, preoperative fasting and water-deprivation regimens, anesthesia regimens, postoperative regimens, postoperative analgesia regimens, postoperative wound care regimens, psychological interventions, and different dosing regimens for antibiotics may affect the health outcomes of diabetic maternal and newborns. However, the quality of evidence was low, and more high-quality clinical research evidence is required.

According to the principle of GRADE method in the evaluation of a prognosis research system, ${ }^{10,11}$ the quality of evidence for each outcome is low, and the reason of downgrading is mainly bias risk and inaccuracy. The bias risks included in the randomized controlled trials were assessed by the Cochrane Bias Risk Assessment Tool, in 


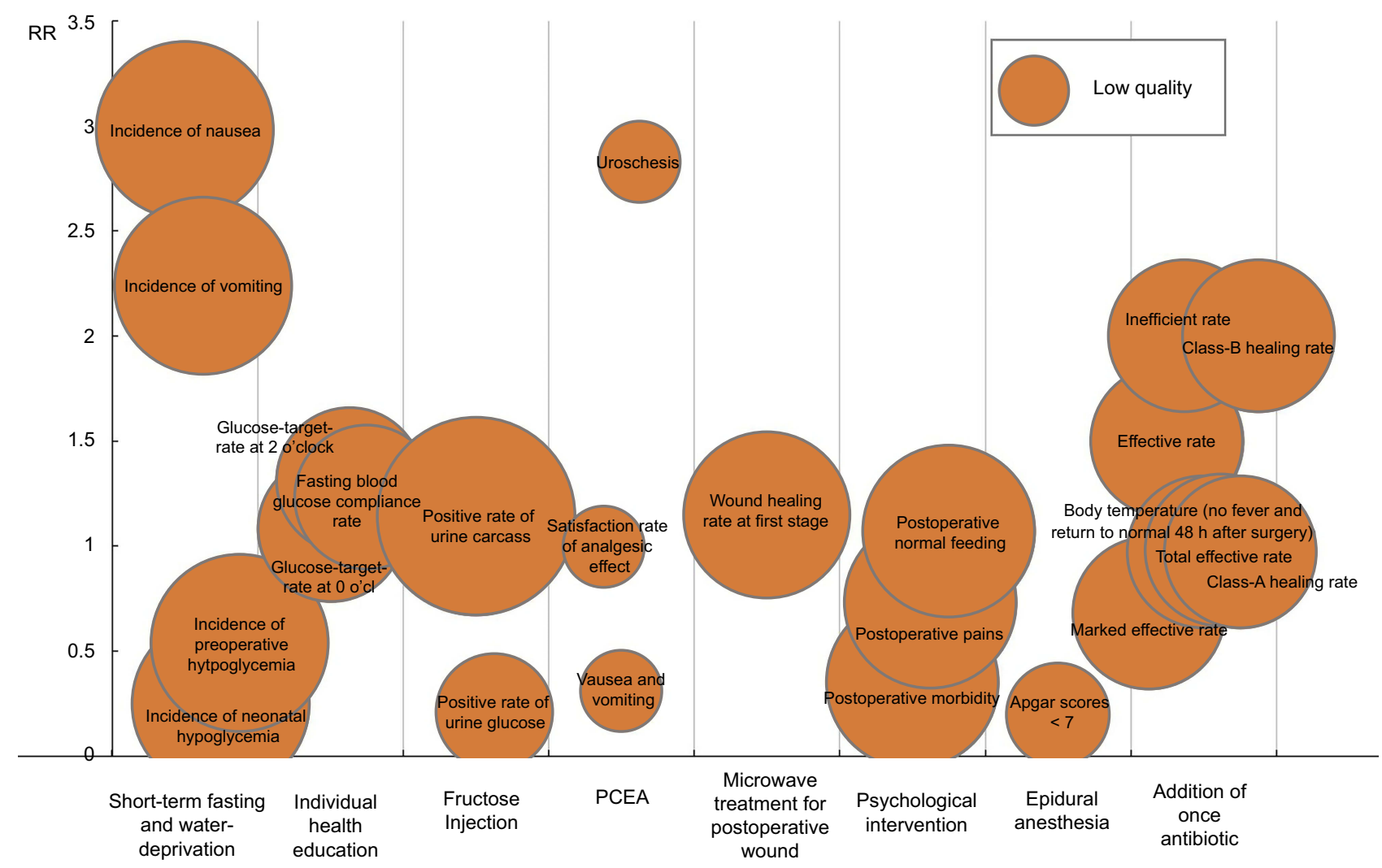

Figure 3 Summary of risk ratio and quality of evidence of outcomes for the prognostic factors with the bubble diagram. Abbreviation: PCEA, patient-controlled epidural analgesia.

which the main source of bias was the nonreported random sequence generation and allocation concealment, which did not blind the researchers, the patients, and the outcome evaluators, and did not report the source of the information and the method of recruiting or joining the patients. The reason for the imprecision is that the sample size is less than the optimal sample size, and the CI of the effect sizes spans the invalid line. For publication bias, as the number of included studies was $<10$, the publication bias was not evaluated using a funnel plot. In addition, the included studies did not report the conflict of interest, considering the research topics and manufacturers that may be the interests of the relationship, and in addition to psychological intervention and obesity factors, the rest of the comparison groups were assessed by the possibility of publication bias. However, it was not possible to quantify the possibility of publication bias; thus, the publication bias was not considered in this study. In addition, because most of outcomes included only 1 study, a few outcomes included only 2 studies, and $\mathrm{I}^{2}$ values are small, it is not been downgraded due to heterogeneity. We performed meta-analyses by using the random effects model for multiple risk factors and outcomes. The qualities of the evidence for all outcomes were low. As the number of studies increases and the quality of the research improves, new research data may change the results of this system review. Therefore, it needs to more new high-quality research to update the review in the future.

The main advantages of this systematic review are: 1) for the first time on the impact of pregnancy in patients with diabetes maternal-perinatal outcome of the perioperative factors were evaluated; 2) the original research carried out a systematic, comprehensive search, greatly reducing the possibility of missing; 3 ) the quality of evidence was graded by GRADE method, and the factors affecting the outcome of perioperative period of cesarean section in pregnant women with diabetes mellitus were clearly presented and interpreted. The limitations of the system review: 1) Only the studies published in Chinese and English were searched, the other languages were not be considered; 2) All the studies are from China, the results may not been applied to other countries and regions. 


\section{Conclusion}

Low-quality evidence shows that perioperative blood glucose management regimens, anesthesia regimens, postoperative fluid regimens, postoperative analgesia regimens, postoperative wound care, and psychological interventions may affect the health outcomes of diabetic maternal and newborns.

\section{Details of ethics approval}

No ethics approval was required or sought for this review.

\section{Data sharing statement}

This review does not involve any analysis of individual patient data.

\section{Acknowledgment}

This review was supported by Beijing Municipal Science and Technology Commission (Project no. D141107005314004).

\section{Disclosure}

The authors report no conflicts of interest in this work.

\section{References}

1. Goldman M, Kitzmiller JL, Abrams B, Cowan RM, Laros RK. Obstetric complications with GDM. Diabetes. 1991;40(Suppl 2):79-82.

2. Gorgal R, Gonçalves E, Barros M, et al. Gestational diabetes mellitus: a risk factor for non-elective cesarean section. $J$ Obstet Gynaecol Res. 2012;38(1):154-159. doi:10.1111/j.14470756.2011.01659.x

3. Martin ET, Kaye KS, Knott C, et al. Diabetes and risk of surgical site infection: a systematic review and meta-analysis. Infect Control Hosp Epidemiol. 2016;37(1):88-99. doi:10.1017/ice.2015.249

4. Leth RA, Uldbjerg N, Nørgaard M, Møller JK, Thomsen RW. Obesity, diabetes, and the risk of infections diagnosed in hospital and post-discharge infections after cesarean section: a prospective cohort study. Acta Obstet Gynecol Scand. 2011;90(5):501-509. doi:10.1111/ j.1600-0412.2011.01090.x

5. Hartling L, Dryden DM, Guthrie A, Muise M, Vandermeer B, Donovan L. Benefits and harms of treating gestational diabetes mellitus: a systematic review and meta-analysis for the U.S. Preventive Services Task Force and the National Institutes of Health Office of Medical Applications of Research. Ann Intern Med. 2013;159(2):123-129. doi:10.7326/0003-4819-159-2-201307 160-00661

6. Nicholson W, Bolen S, Witkop CT, Neale D, Wilson L, Bass E. Benefits and risks of oral diabetes agents compared with insulin in women with gestational diabetes: a systematic review. Obstet Gynecol. 2009;113 (1):193-205. doi:10.1097/AOG.0b013e318190a459

7. Amin M, Suksomboon N, Poolsup N, Malik O. Comparison of glyburide with metformin in treating gestational diabetes mellitus: a systematic review and meta-analysis. Clin Drug Investig. 2015;35 (6):343-351. doi:10.1007/s40261-015-0289-3
8. González Blanco C, Chico Ballesteros A, Gich Saladich I, Corcoy Pla R. Glycemic control and pregnancy outcomes in women with type 1 diabetes mellitus using lispro versus regular insulin: a systematic review and meta-analysis. Diabetes Technol Ther. 2011;13(9):907-911. doi:10.1089/dia.2011.0032

9. Lv S, Wang J, Xu Y. Safety of insulin analogs during pregnancy: a meta-analysis. Arch Gynecol Obstet. 2015;292(4):749-756. doi:10.1007/s00404-015-3692-3

10. Zeng YC, Li MJ, Chen Y, et al. The use of glyburide in the management of gestational diabetes mellitus: a meta-analysis. Adv Med Sci. 2014;59(1):95-101. doi:10.1016/j.advms.2014.03.001

11. Viana LV, Gross JL, Azevedo MJ. Dietary intervention in patients with gestational diabetes mellitus: a systematic review and meta-analysis of randomized clinical trials on maternal and newborn outcomes. Diabetes Care. 2014;37(12):3345-3355. doi:10.2337/dc14-1530

12. Thomaz de Lima H, Lopes Rosado E, Ribeiro Neves PA, et al. Systematic review; Nutritional therapy in gestational diabetes mellitus. Nutr Hosp. 2013;28(6):1806-1814. doi:10.3305/nutrhosp. v28in06.6892

13. Datta S, Brown WU Jr. Acid-base status in diabetic mothers and their infants following general or spinal anesthesia for cesarean section. Anesthesiology. 1977;47(3):272-276.

14. Yin X. The clinical effectiveness of different methods of anesthesia for the puerperants with gestational diabetes mellitus. Chin J Mod Drug Appl. 2015;9(17):128-130. Chinese.

15. Zheng W, Huang X. The analysis of hypopiesia led by different options of anesthesia for the patients with gestational diabetes mellitus in cesarean section. Contemp Med Forum. 2015;13(16):221-222. Chinese.

16. Wang X, Jin Z, Xu Q, et al. Effects of fructose on metabolic changes after cesarean section in gestational diabetes mellitus patients. Chin J Pract Gynecol Obstet. 2010;26(12):933-935. Chinese.

17. Yu R. The effect of fructose in fusion on the levels of blood glucose and insulin in gestationai diabetes mellitus patients after cesarean section. Strait Pharm J. 2014;26(12):102-105. Chinese.

18. Chen H. The analysis of effectiveness of microwave therapy for surgical site healing in the puerperae with diabetes. Henan Med Res. 2015;24(11):76-77. Chinese.

19. Huguet A, Hayden JA, Stinson J, et al. Judging the quality of evidence in reviews of prognostic factor research: adapting the GRADE framework. Syst Rev. 2013;2:71. doi:10.1186/2046-4053-2-71

20. Iorio A, Spencer FA, Falavigna M, et al. Use of GRADE for assessment of evidence about prognosis: rating confidence in estimates of event rates in broad categories of patients. BMJ. 2015;350:h870. doi:10.1136/bmj.h870

21. Goldsmith R, Wright C, Bell SF, Rushton A. Cold hyperalgesia as a prognostic factor in whiplash associated disorders: a systematic review. Man Ther. 2012;17(5):402-410. doi:10.1016/j.math.2012. 02.014

22. Han M. The applying of psychological interventions for the patients with gestational diabetes mellitus in peri-operative period. Chin J Prim Bled Pharm. 2015;22(5):757-759. Chinese.

23. Li D, Liu Z, Xu P, et al. The effect of music therapy for anxiety and hemodynamics of gestational diabetes mellitus patients with cesarean section. J Hebei Med Univ. 2015;36(12):1464-1466. Chinese.

24. Zhao L, Zhai J, Shen X. The effect of two analgesia options on the blood sugar of gestational diabetes mellitus patients with cesarean section. Shanghai Med J. 2011;34(12):955-956. Chinese.

25. Li N, Zhang H, Jiang S. The effectiveness of peri-operative insulin pump on the patients with gestational diabetes mellitus. Chin J Misdiagn. 2010;10(12):2845-2846. Chinese.

26. Zhang Y, Zhao Y, Zhao E, et al. The effectiveness of small dose of sulfentanyl combining with bupivacaine on cesarean section in the puerperants with gestational diabetes mellitus. China Pharm. 2015;24 (1):9-10. Chinese. 
27. Feng J, Bao A, Lu Y, et al. Effects of preoperative fasting and liquid-fasting time before caesarean section on blood glucose of puerperae with GDM and neonates. Chin J Mod Nurs. 2017;23 (4):509-512. Chinese.

28. Wang T, Miao P, Hu J. Effects of individualized health education on blood glucose after cesarean section in diabetes mellitus with pregnancy. Contemp Med. 2017;23(27):168-170. Chinese.
29. Yang G, Abulaiti Z, Qian Y, et al. Effect comparison of different antibiotic regimens in the prevention infection after cesarean in patients with gestational diabetes mellitus. Xinjiang Med J. 2017;47(4):366-368.

30. Hod M, Kapur A, Sacks DA, et al. The International Federation of Gynecology and Obstetrics (FIGO) Initiative on gestational diabetes mellitus: A pragmatic guide for diagnosis, management, and care. Int J Gynaecol Obstet. 2015;131(Suppl 3):S173-S211. doi:10.1016/ S0020-7292(15)30033-3 


\section{Supplementary materials}

Appendix I. Effect evaluation results

\begin{tabular}{|c|c|c|c|c|}
\hline Outcome & $\begin{array}{l}\text { No. of } \\
\text { studies }\end{array}$ & $\begin{array}{l}\text { No. of } \\
\text { participants }\end{array}$ & $\begin{array}{l}\text { Effect estimate } \\
\text { RR/MD }(95 \% \mathrm{Cl})\end{array}$ & $P$ value \\
\hline \multicolumn{5}{|l|}{ Insulin pump VS multiple subcutaneous injections of insulin } \\
\hline Blood glucose standard time (d) & 1 & 48 & MD: $-5.30(-5.78,-4.82)$ & $<0.00001$ \\
\hline Dose of insulin (U/d) & 1 & 48 & $\begin{array}{l}\text { MD: - I } 7.00(-23.04 \\
-10.96)\end{array}$ & $<0.00001$ \\
\hline Surgical incision healing time $/ \mathrm{d}$ & 1 & 48 & MD: $-4.40(-5.58,-3.22)$ & $<0.00001$ \\
\hline \multicolumn{5}{|l|}{ Fasting and water-deprivation: short-term VS long-term } \\
\hline Preoperative blood glucose (mmol/L) & 1 & 162 & MD: $0.84(0.42,1.26)$ & 0.001 \\
\hline Postoperative blood glucose(mmol/L) & 1 & 162 & MD: $0.16(-0.17,0.49)$ & 0.345 \\
\hline Incidence of nausea & I & 162 & RR: $2.98(0.77, \mid I .5 I)$ & 0.180 \\
\hline Incidence of vomiting & 1 & 162 & RR: $2.24(0.38,13.03)$ & 0.647 \\
\hline Incidence of neonatal hypoglycemia & 1 & 162 & RR: $0.25(0.03,2.02)$ & 0.302 \\
\hline Incidence of preoperative hypoglycemia & 1 & 162 & RR: $0.54(0.18,1.63)$ & 0.264 \\
\hline Maternal anal discharge time $(\mathrm{h})$ & 1 & 162 & MD: $-0.04(-0.25,0.17)$ & 0.692 \\
\hline Bleeding during childbirth (ml) & 1 & 162 & MD: -42.7 I (-82.55, -2.86) & 0.039 \\
\hline Neonatal Apgar scores at I min & 1 & 162 & MD: $0.03(-0.18,0.24)$ & 0.918 \\
\hline Neonatal Apgar scores at $5 \mathrm{~min}$ & I & 162 & MD: $-0.03(-0.14,0.08)$ & 0.183 \\
\hline Postnatal blood glucose (mmol/L) & 1 & 162 & MD: $0.45(0.03,0.87)$ & 0.038 \\
\hline \multicolumn{5}{|l|}{ Health education: individualization VS convention } \\
\hline Fasting blood glucose compliance rate & 1 & 110 & RR: $1.08(0.86,1.35)$ & $>0.05$ \\
\hline Glucose-target-rate at 2 o'clock & 1 & 110 & RR: I.3 I (1.04, I.66) & $<0.05$ \\
\hline Glucose-target-rate at 0 o'cl & 1 & 110 & RR: I.23 (1.01, I.50) & $<0.05$ \\
\hline Nursing service satisfaction & I & 110 & MD: 6.5 I $(5.80,7.22)$ & $<0.01$ \\
\hline \multicolumn{5}{|l|}{ Fructose Injection VS Glucose Injection + Insulin } \\
\hline Blood glucose level at $1.5 \sim 2 \mathrm{~h}$ after infusion ( $\mathrm{mmol} / \mathrm{L}$ ) & 2 & 202 & MD: - $1.17(-1.93,-0.41)$ & 0.003 \\
\hline Blood glucose level at $3 \sim 4 \mathrm{~h}$ after infusion (mmol/L) & 2 & 202 & MD: $-0.99(-1.6 I,-0.36)$ & 0.002 \\
\hline Blood glucose level at $6 \mathrm{~h}$ after infusion (mmol/L) & 1 & 70 & MD: $-0.62(-I .86,0.6 I)$ & 0.32 \\
\hline Insulin level at $1.5 \mathrm{~h}$ after infusion (mU/L) & 1 & 132 & MD: - $13.50(-19.02,-7.98)$ & $<0.0000$ I \\
\hline Insulin level at $3 \mathrm{~h}$ after infusion (mU/L) & 1 & 132 & MD: $-8.59(-13.75,-3.43)$ & 0.001 \\
\hline Blood uric acid level at $3 \mathrm{~h}$ after infusion $(\mu \mathrm{mol} / \mathrm{L})$ & 1 & 132 & MD: $-8.00(-34.96,18.96)$ & 0.56 \\
\hline Positive rate of urine carcass & 2 & 202 & RR: I.I4 (0.49, 2.64) & 0.77 \\
\hline Positive rate of urine glucose & I & 70 & RR: $0.21(0.01,4.25)$ & 0.31 \\
\hline \multicolumn{5}{|l|}{ PCEA VS PCIA } \\
\hline Blood glucose level at $3 \mathrm{~h}$ after the onset of analgesia (mmol/L) & 1 & 33 & MD: $0.01(-0.21,0.23)$ & 0.93 \\
\hline Blood glucose level at $3 \mathrm{~h}$ after the onset of analgesia $(\mathrm{mmol} / \mathrm{L})$ & 1 & 33 & MD: $-0.80(-1.01,-0.59)$ & $<0.00001$ \\
\hline Blood glucose level at $12 \mathrm{~h}$ after the onset of analgesia $(\mathrm{mmol} / \mathrm{L})$ & 1 & 33 & MD: $-0.76(-1.00,-0.52)$ & $<0.00001$ \\
\hline Blood glucose level at $24 \mathrm{~h}$ after the onset of analgesia $(\mathrm{mmol} / \mathrm{L})$ & 1 & 33 & MD: $-0.65(-0.87,-0.43)$ & $<0.0000$ I \\
\hline Blood glucose level at $36 \mathrm{~h}$ after the onset of analgesia $(\mathrm{mmol} / \mathrm{L})$ & 1 & 33 & MD: $-0.75(-0.96,-0.54)$ & $<0.0000$ I \\
\hline VAS score at $36 \mathrm{~h}$ after the onset of analgesia $(\mathrm{mmol} / \mathrm{L})$ & 1 & 33 & MD: $-0.04(-0.31,0.23)$ & 0.77 \\
\hline VAS score at $6 \mathrm{~h}$ after the onset of analgesia $(\mathrm{mmol} / \mathrm{L})$ & 1 & 33 & MD: $-0.01(-0.20,0.18)$ & 0.92 \\
\hline VAS score at $12 \mathrm{~h}$ after the onset of analgesia $(\mathrm{mmol} / \mathrm{L})$ & 1 & 33 & MD: $-0.02(-0.24,0.20)$ & 0.86 \\
\hline VAS score at $24 \mathrm{~h}$ after the onset of analgesia $(\mathrm{mmol} / \mathrm{L})$ & 1 & 33 & MD: $-0.05(-0.39,0.29)$ & 0.77 \\
\hline VAS score at $36 \mathrm{~h}$ after the onset of analgesia $(\mathrm{mmol} / \mathrm{L})$ & I & 33 & MD: $-0.04(-0.35,0.27)$ & 0.80 \\
\hline
\end{tabular}

(Continued) 
Appendix I. (Continued).

\begin{tabular}{|c|c|c|c|c|}
\hline Outcome & $\begin{array}{l}\text { No. of } \\
\text { studies }\end{array}$ & $\begin{array}{l}\text { No. of } \\
\text { participants }\end{array}$ & $\begin{array}{l}\text { Effect estimate } \\
\text { RR/MD }(95 \% \mathrm{Cl})\end{array}$ & $P$ value \\
\hline Satisfaction rate of analgesic effect & 1 & 33 & RR: $1.00(0.89,1.12)$ & 1.00 \\
\hline Vausea and vomiting & I & 33 & RR: 0.31 (0.0I, 7.2I) & 0.47 \\
\hline Uroschesis & 1 & 33 & RR: $2.83(0.12,64.89)$ & 0.51 \\
\hline \multicolumn{5}{|l|}{ Postoperative wound care: microwave treatment of VS routine care } \\
\hline Wound healing rate at first stage & I & 140 & RR: I.I5 (I.03, I.29) & 0.01 \\
\hline \multicolumn{5}{|l|}{ Psychological intervention (including music therapy) VS routine care } \\
\hline Systolic pressure immediately into the operating room (mmHg) & I & 200 & MD: $-9.80(-12.42,-7.18)$ & $<0.00001$ \\
\hline $\begin{array}{l}\text { Systolic pressure after surgery into the operating room 30min } \\
(\mathrm{mmHg})\end{array}$ & 1 & 200 & $\begin{array}{l}\text { MD: }-35.37(-38.32 \\
-32.42)\end{array}$ & $<0.00001$ \\
\hline Intraoperative systolic pressure $(\mathrm{mmHg})$ & I & 153 & $\begin{array}{l}\text { MD: }-22.63(-27.24, \\
-18.02)\end{array}$ & $<0.00001$ \\
\hline Diastolic pressure immediately into the operating room $(\mathrm{mmHg})$ & I & 200 & MD: -3.58 (-5.20, - -1.96) & $<0.00001$ \\
\hline $\begin{array}{l}\text { Diastolic pressure after surgery into the operating room } 30 \mathrm{~min} \\
(\mathrm{mmHg})\end{array}$ & I & 200 & MD: -7.58 (-9.62, -5.54$)$ & $<0.00001$ \\
\hline Intraoperative diastolic pressure $(\mathrm{mmHg})$ & 1 & 153 & MD: - $10.61(-14.65,-6.57)$ & $<0.00001$ \\
\hline Heart rate immediately into the operating room & 1 & 200 & MD: $-0.86(-2.69,0.97)$ & 0.36 \\
\hline Heart rate after surgery into the operating room $30 \mathrm{~min}$ & 1 & 200 & MD: $-8.89(-10.52,-7.26)$ & $<0.00001$ \\
\hline Anxiety score immediately into the operating room & I & 200 & MD: $-0.13(-2.57,2.31)$ & 0.92 \\
\hline Anxiety score after surgery into the operating room $30 \mathrm{~min}$ & 1 & 200 & MD: $-2.22(-3.55,-0.89)$ & 0.001 \\
\hline Intro-operative hemorrhage (ml) & I & 153 & $\begin{array}{l}\text { MD: -62.39 (-78.3I, } \\
-46.47)\end{array}$ & $<0.00001$ \\
\hline Postoperative morbidity & I & 153 & RR: $0.35(0.19,0.64)$ & 0.0008 \\
\hline Postoperative pains & I & 153 & RR: $0.73(0.60,0.89)$ & 0.002 \\
\hline Postoperative normal feeding & I & 153 & RR: I.07 (0.99, I.16) & 0.09 \\
\hline \multicolumn{5}{|l|}{ Epidural anesthesia vs general anesthesia } \\
\hline Blood glucose while skin cutting (mmol/L) & I & 54 & MD: 1.48 (I.3I, I.65) & $<0.00001$ \\
\hline Blood glucose while delivery of the fetus (mmol/L) & I & 54 & MD: $0.00(-0.17,0.17)$ & 1.00 \\
\hline Blood glucose while delivery of placenta(mmol/L) & I & 54 & MD: $-0.19(-0.37,-0.01)$ & 0.04 \\
\hline Blood glucose about 2 hours after delivery of the fetus $(\mathrm{mmol} / \mathrm{L})$ & I & 54 & MD: 0.90 (0.7I, I.09) & $<0.00001$ \\
\hline Blood glucose about 6 hours after delivery of the fetus ( $\mathrm{mmol} / \mathrm{L}$ ) & I & 54 & MD: I.II (0.93, I.29) & $<0.00001$ \\
\hline Apgar scores $<7$ & I & 54 & RR: $0.20(0.01,3.98)$ & 0.29 \\
\hline \multicolumn{5}{|c|}{ Combined spinal and epidural analgesia: low dose sufentanil combined with bupivacaine VS bupivacaine } \\
\hline Blood glucose while skin cutting (mmol/L) & I & 66 & MD: - I.45 (-1.6I, -I.29) & $<0.00001$ \\
\hline Blood glucose while delivery of the fetus (mmol/L) & I & 66 & MD: $0.01(-0.13,0.15)$ & 0.89 \\
\hline Blood glucose about $5 \mathrm{~min}$ after delivery of placenta $(\mathrm{mmol} / \mathrm{L})$ & I & 66 & MD: $0.23(0.06,0.40)$ & 0.009 \\
\hline Blood glucose about $2 \mathrm{~h}$ after delivery of the fetus ( $\mathrm{mmol} / \mathrm{L})$ & 1 & 66 & MD: - $0.89(-1.07,-0.7 I)$ & $<0.00001$ \\
\hline
\end{tabular}

(Continued) 
Appendix I. (Continued).

\begin{tabular}{|c|c|c|c|c|}
\hline Outcome & $\begin{array}{l}\text { No. of } \\
\text { studies }\end{array}$ & $\begin{array}{l}\text { No. of } \\
\text { participants }\end{array}$ & $\begin{array}{l}\text { Effect estimate } \\
\text { RR/MD }(95 \% \mathrm{Cl})\end{array}$ & $P$ value \\
\hline Mean arterial pressure at I min after anesthesia $(\mathrm{mmHg})$ & I & 66 & MD: $0.40(-2.11,2.9 I)$ & 0.75 \\
\hline Mean arterial pressure at $2 \mathrm{~min}$ after anesthesia $(\mathrm{mmHg})$ & 1 & 66 & MD: $1.40(-1.62,4.42)$ & 0.36 \\
\hline Mean arterial pressure at $5 \mathrm{~min}$ after anesthesia $(\mathrm{mmHg})$ & 1 & 66 & MD: $5.80(3.12,8.48)$ & $<0.00001$ \\
\hline Mean arterial pressure at 10 min after anesthesia $(\mathrm{mmHg})$ & I & 66 & MD: $0.30(-2.47,3.07)$ & 0.83 \\
\hline Mean arterial pressure at $20 \mathrm{~min}$ after anesthesia $(\mathrm{mmHg})$ & I & 66 & MD: $1.90(-1.10,4.90)$ & 0.21 \\
\hline Apgar score at I min & I & 66 & MD: $0.10(-0.17,0.37)$ & 0.46 \\
\hline Apgar score at $5 \mathrm{~min}$ & 1 & 66 & MD: $0.10(0.02,0.18)$ & 0.01 \\
\hline \multicolumn{5}{|l|}{ Additional an antibiotic once vs. 24 -h antibiotic application } \\
\hline Marked effective rate & 1 & 120 & RR: $0.68(0.48,0.97)$ & $<0.05$ \\
\hline Effective rate & I & 120 & RR: I.50 (0.97, 2.33) & $>0.05$ \\
\hline Inefficient rate & 1 & 120 & RR: $2.00(0.38,10.5 I)$ & $>0.05$ \\
\hline Total effective rate & I & 120 & RR: $0.97(0.89,1.05)$ & $>0.05$ \\
\hline WBC $<12 \times 10^{9} / \mathrm{L}$ time (d) & 1 & 120 & MD: $0.50(-0.02,1.02)$ & $>0.05$ \\
\hline Body temperature (no fever and return to normal $48 \mathrm{~h}$ after surgery) & I & 120 & RR: $0.98(0.93,1.04)$ & $>0.05$ \\
\hline Class- $\mathrm{A}$ healing rate & I & 120 & RR: $0.97(0.89,1.05)$ & $>0.05$ \\
\hline Class- $B$ healing rate & I & 120 & RR: $2.00(0.38, \mid 0.5 \mathrm{I})$ & $>0.05$ \\
\hline Class- $C$ healing rate & I & 120 & - & $>0.05$ \\
\hline
\end{tabular}

Notes: Bold values indicate statistical significance if the interval does not cross zero for continuous outcomes with MD, and cross one for dichotomous outcomes with RR. The bold values also mean the effect or difference was statistically significant.

Abbreviation: MD, mean difference. 
Appendix 2. Summary of Evidence

\begin{tabular}{|c|c|c|c|c|c|}
\hline \multirow[t]{2}{*}{ Outcomes } & \multirow{2}{*}{$\begin{array}{l}\text { No of partici- } \\
\text { pants(studies) } \\
\text { Follow-up }\end{array}$} & \multirow{2}{*}{$\begin{array}{l}\text { Quality of the } \\
\text { evidence } \\
\text { (GRADE) }\end{array}$} & \multirow{2}{*}{$\begin{array}{l}\text { Relative } \\
\text { effect } \\
(95 \% \mathrm{CI})\end{array}$} & \multicolumn{2}{|l|}{$\begin{array}{l}\text { Anticipated } \\
\text { absolute effects }\end{array}$} \\
\hline & & & & $\begin{array}{l}\text { Risk with } \\
\text { control group }\end{array}$ & $\begin{array}{l}\text { Risk difference } \\
\text { with observation } \\
\text { group }\end{array}$ \\
\hline \multicolumn{6}{|c|}{ Insulin pump VS multiple subcutaneous injections of insulin } \\
\hline Blood glucose standard time (d) & 48 (I RCT) & LOW $^{1,2}$ & - & - & $\begin{array}{l}\text { MD } 5.3 \text { fewer(5.78 } \\
\text { fewer to } 4.82 \text { fewer) }\end{array}$ \\
\hline Dose of insulin (U/d) & 48 (I RCT) & $\operatorname{LOW}^{1,2}$ & - & - & $\begin{array}{l}\text { MD } 17 \text { fewer( } 23.04 \\
\text { fewer to } 10.96 \\
\text { fewer) }\end{array}$ \\
\hline Surgical incision healing time $/ \mathrm{d}$ & 48 (I RCT) & $\operatorname{LOW}^{1,2}$ & - & - & $\begin{array}{l}\text { MD } 4.4 \text { fewer(5.58 } \\
\text { fewer to } 3.22 \text { fewer) }\end{array}$ \\
\hline \multicolumn{6}{|c|}{ Fasting and water-deprivation: short-term VS long-term } \\
\hline $\begin{array}{l}\text { Preoperative blood glucose } \\
\text { (mmol/L) }\end{array}$ & $162($ ( RCT) & $\operatorname{LOW}^{1,2}$ & - & - & $\begin{array}{l}\text { MD } 0.84 \text { more }(0.42 \\
\text { more to } 1.26 \text { more })\end{array}$ \\
\hline $\begin{array}{l}\text { Postoperative blood glucose } \\
\text { (mmol/L) }\end{array}$ & $162($ ( RCT) & LOW $^{1,5}$ & - & - & $\begin{array}{l}\text { MD } 0.16 \text { more }(0.17 \\
\text { fewer to } 0.49 \text { more })\end{array}$ \\
\hline Incidence of nausea & 162 (I RCT) & LOW ${ }^{1,5}$ & $\begin{array}{l}\text { RR } 2.98(0.77 \\
\text { to } 11.51)\end{array}$ & 62 per 1,000 & $\begin{array}{l}15 \text { more per } 1,000(61 \\
\text { fewer to } 152 \text { more) }\end{array}$ \\
\hline Incidence of vomiting & $162($ ( RCT) & $\operatorname{LOW}^{1,5}$ & $\begin{array}{l}\text { RR } 2.24(0.38 \\
\text { to } 13.03)\end{array}$ & 21 per 1,000 & $\begin{array}{l}26 \text { more per } 1,000(13 \\
\text { fewer to } 248 \text { more) }\end{array}$ \\
\hline $\begin{array}{l}\text { Incidence of neonatal } \\
\text { hypoglycemia }\end{array}$ & 162 (I RCT) & LOW ${ }^{1,5}$ & $\begin{array}{l}\text { RR } 0.25(0.03 \\
\text { to } 2.02)\end{array}$ & 62 per 1,000 & $\begin{array}{l}47 \text { fewer per } 1,000(60 \\
\text { fewer to } 63 \text { more) }\end{array}$ \\
\hline $\begin{array}{l}\text { Incidence of preoperative } \\
\text { hypoglycemia }\end{array}$ & 162 (I RCT) & $\operatorname{LOW}^{1,5}$ & $\begin{array}{l}\text { RR } 0.54(0.18 \\
\text { to } 1.63)\end{array}$ & 113 per 1,000 & $\begin{array}{l}52 \text { fewer per } 1,000(93 \\
\text { fewer to } 71 \text { more) }\end{array}$ \\
\hline Maternal anal discharge time(h) & I62 (I RCT) & $\operatorname{LOW}^{1,5}$ & - & - & $\begin{array}{l}\text { MD } 0.04 \text { fewer( } 0.25 \\
\text { fewer to } 0.17 \text { more) }\end{array}$ \\
\hline Bleeding during childbirth $(\mathrm{ml})$ & $162($ ( RCT) & $\operatorname{LOW}^{1,2}$ & - & - & $\begin{array}{l}\text { MD } 42.71 \text { fewer } \\
\text { (82.55 fewer to } 2.86 \\
\text { fewer) }\end{array}$ \\
\hline Neonatal Apgar scores at I min & $162($ ( RCT) & LOW ${ }^{1,5}$ & - & - & $\begin{array}{l}\text { MD } 0.03 \text { more }(0.18 \\
\text { fewer to } 0.24 \text { more })\end{array}$ \\
\hline Neonatal Apgar scores at $5 \mathrm{~min}$ & I62 (I RCT) & LOW $^{1,5}$ & - & - & $\begin{array}{l}\text { MD } 0.03 \text { fewer( } 0.14 \\
\text { fewer to } 0.08 \text { more) }\end{array}$ \\
\hline Postnatal blood glucose (mmol/L) & $162($ I RCT) & LOW ${ }^{1,5}$ & - & - & $\begin{array}{l}\text { MD } 0.45 \text { more }(0.03 \\
\text { fewer to } 0.87 \text { more })\end{array}$ \\
\hline \multicolumn{6}{|c|}{ Health education: individualization VS convention } \\
\hline $\begin{array}{l}\text { Fasting blood glucose compli- } \\
\text { ance rate }\end{array}$ & IIO (I RCT) & LOW ${ }^{1,5}$ & $\begin{array}{l}\text { RR I.08(0.86 } \\
\text { to I.35) }\end{array}$ & 764 per 1,000 & $\begin{array}{l}61 \text { more per I,000(107 } \\
\text { fewer to } 267 \text { more) }\end{array}$ \\
\hline Glucose-target-rate at 2 o'clock & $110(\mathrm{I} R C T)$ & $\operatorname{LOW}^{1,2}$ & $\begin{array}{l}\text { RR } 1.31(1.04 \\
\text { to } 1.66)\end{array}$ & 836 per 1,000 & $\begin{array}{l}259 \text { more per } 1,000 \\
(33 \text { more to } 552 \\
\text { more) }\end{array}$ \\
\hline Glucose-target-rate at 0 o'cl & IIO (I RCT) & $\operatorname{LOW}^{1,2}$ & $\begin{array}{l}\text { RR I.23(I.0I } \\
\text { to I.50) }\end{array}$ & 873 per 1,000 & $\begin{array}{l}201 \text { more per } 1,000 \\
(9 \text { more to } 436 \\
\text { more) }\end{array}$ \\
\hline Nursing service satisfaction & $110(\mathrm{I} R C T)$ & $\operatorname{LOW}^{1,2}$ & - & - & $\begin{array}{l}\text { MD } 6.51 \text { more(5.80 } \\
\text { more to } 7.22 \text { more) }\end{array}$ \\
\hline
\end{tabular}


Appendix 2. (Continued).

\begin{tabular}{|c|c|c|c|c|c|}
\hline \multirow[t]{2}{*}{ Outcomes } & \multirow{2}{*}{$\begin{array}{l}\text { No of partici- } \\
\text { pants(studies) } \\
\text { Follow-up }\end{array}$} & \multirow{2}{*}{$\begin{array}{l}\text { Quality of the } \\
\text { evidence } \\
\text { (GRADE) }\end{array}$} & \multirow{2}{*}{$\begin{array}{l}\text { Relative } \\
\text { effect } \\
(95 \% \mathrm{CI})\end{array}$} & \multicolumn{2}{|l|}{$\begin{array}{l}\text { Anticipated } \\
\text { absolute effects }\end{array}$} \\
\hline & & & & $\begin{array}{l}\text { Risk with } \\
\text { control group }\end{array}$ & $\begin{array}{l}\text { Risk difference } \\
\text { with observation } \\
\text { group }\end{array}$ \\
\hline \multicolumn{6}{|c|}{ Fructose Injection vs. Glucose Injection + Insulin } \\
\hline $\begin{array}{l}\text { Blood glucose level at I.5 2 } \mathrm{h} \\
\text { after infusion }(\mathrm{mmol} / \mathrm{L})\end{array}$ & 202 (2 RCTs) & $\operatorname{LOW}^{2,3}$ & - & - & $\begin{array}{l}\text { MD } 1.17 \text { fewer( } 1.93 \\
\text { fewer to } 0.41 \text { fewer })\end{array}$ \\
\hline $\begin{array}{l}\text { Blood glucose level at } 3 \sim 4 \mathrm{~h} \\
\text { after infusion (mmol/L) }\end{array}$ & 202 (2 RCTs) & $\operatorname{LOW}^{2,3}$ & - & - & $\begin{array}{l}\text { MD } 0.99 \text { fewer( } 1.61 \\
\text { fewer to } 0.36 \text { fewer) }\end{array}$ \\
\hline $\begin{array}{l}\text { Blood glucose level at } 6 \mathrm{~h} \text { after } \\
\text { infusion }(\mathrm{mmol} / \mathrm{L})\end{array}$ & 70 (I RCT) & $\operatorname{LOW}^{4,5}$ & - & - & $\begin{array}{l}\text { MD } 0.62 \text { fewer(I.86 } \\
\text { fewer to } 0.61 \text { more) }\end{array}$ \\
\hline $\begin{array}{l}\text { Insulin level at } 1.5 \mathrm{~h} \text { after infu- } \\
\text { sion }(\mathrm{mU} / \mathrm{L})\end{array}$ & I 32 (I RCT) & LOW $^{2,4}$ & - & & $\begin{array}{l}\text { MD I3.5 fewer } \\
\text { (19.02 fewer to } 7.98 \\
\text { fewer) }\end{array}$ \\
\hline $\begin{array}{l}\text { Insulin level at } 3 \mathrm{~h} \text { after infusion } \\
(\mathrm{mU} / \mathrm{L})\end{array}$ & I32 (I RCT) & $\operatorname{LOW}^{2,4}$ & - & & $\begin{array}{l}\text { MD } 8.59 \text { fewer } \\
\text { (13.75 fewer to } 3.43 \\
\text { fewer) }\end{array}$ \\
\hline $\begin{array}{l}\text { Blood uric acid level at } 3 \mathrm{~h} \text { after } \\
\text { infusion }(\mu \mathrm{mol} / \mathrm{L})\end{array}$ & I32 (I RCT) & $\operatorname{LOW}^{4,5}$ & - & & $\begin{array}{l}\text { MD } 8 \text { fewer( } 34.96 \\
\text { fewer to } 18.96 \text { more) }\end{array}$ \\
\hline Positive rate of urine carcass & 202 (2 RCTs) & $\operatorname{LOW}^{3,5}$ & $\begin{array}{l}\text { OR I.I } 4(0.49 \\
\text { to } 2.64)\end{array}$ & 129 per 1,000 & $\begin{array}{l}15 \text { more per } 1,000(61 \\
\text { fewer to } 152 \text { more) }\end{array}$ \\
\hline Positive rate of urine glucose & 70 (I RCT) & $\operatorname{LOW}^{1,5}$ & $\begin{array}{l}\text { RR } 0.21(0.01 \\
\text { to } 4.25)\end{array}$ & 56 per 1,000 & $\begin{array}{l}44 \text { fewer per } 1,000(55 \\
\text { fewer to } 181 \text { more) }\end{array}$ \\
\hline \multicolumn{6}{|l|}{ PCEA VS PCIA } \\
\hline $\begin{array}{l}\text { Blood glucose level at } 3 \mathrm{~h} \text { after } \\
\text { the onset of analgesia ( } \mathrm{mmol} / \mathrm{L})\end{array}$ & 33 (I RCT) & $\operatorname{LOW}^{1,5}$ & - & - & $\begin{array}{l}\text { MD } 0.01 \text { more }(0.21 \\
\text { fewer to } 0.23 \text { more })\end{array}$ \\
\hline $\begin{array}{l}\text { Blood glucose level at } 3 \mathrm{~h} \text { after } \\
\text { the onset of analgesia }(\mathrm{mmol} / \mathrm{L})\end{array}$ & 33 (I RCT) & $\operatorname{LOW}^{1,2}$ & - & - & $\begin{array}{l}\text { MD } 0.8 \text { fewer( } 1.01 \\
\text { fewer to } 0.59 \text { fewer) }\end{array}$ \\
\hline $\begin{array}{l}\text { Blood glucose level at } 12 \mathrm{~h} \text { after } \\
\text { the onset of analgesia }(\mathrm{mmol} / \mathrm{L})\end{array}$ & 33 (I RCT) & $\operatorname{LOW}^{1,2}$ & - & - & $\begin{array}{l}\text { MD } 0.76 \text { fewer( }( \\
\text { fewer to } 0.52 \text { fewer) }\end{array}$ \\
\hline $\begin{array}{l}\text { Blood glucose level at } 24 \mathrm{~h} \text { after } \\
\text { the onset of analgesia }(\mathrm{mmol} / \mathrm{L})\end{array}$ & 33 (I RCT) & $\operatorname{LOW}^{1,2}$ & - & & $\begin{array}{l}\text { MD } 0.65 \text { fewer( } 0.87 \\
\text { fewer to } 0.43 \text { fewer) }\end{array}$ \\
\hline $\begin{array}{l}\text { Blood glucose level at } 36 \mathrm{~h} \text { after } \\
\text { the onset of analgesia }(\mathrm{mmol} / \mathrm{L})\end{array}$ & 33 (I RCT) & $\operatorname{LOW}^{1,2}$ & - & - & $\begin{array}{l}\text { MD } 0.75 \text { fewer( } 0.96 \\
\text { fewer to } 0.54 \text { fewer) }\end{array}$ \\
\hline $\begin{array}{l}\text { VAS score at } 36 \mathrm{~h} \text { after the onset } \\
\text { of analgesia }(\mathrm{mmol} / \mathrm{L})\end{array}$ & 33 (I RCT) & LOW $^{1,5}$ & - & - & $\begin{array}{l}\text { MD } 0.04 \text { fewer( } 0.31 \\
\text { fewer to } 0.23 \text { more })\end{array}$ \\
\hline $\begin{array}{l}\text { VAS score at } 6 \mathrm{~h} \text { after the onset } \\
\text { of analgesia }(\mathrm{mmol} / \mathrm{L})\end{array}$ & 33 (I RCT) & $\operatorname{LOW}^{1,5}$ & - & & $\begin{array}{l}\text { MD } 0.01 \text { fewer( } 0.2 \\
\text { fewer to } 0.18 \text { more })\end{array}$ \\
\hline $\begin{array}{l}\text { VAS score at } 12 \mathrm{~h} \text { after the onset } \\
\text { of analgesia }(\mathrm{mmol} / \mathrm{L})\end{array}$ & 33 (I RCT) & $\operatorname{LOW}^{1,5}$ & - & & $\begin{array}{l}\text { MD } 0.02 \text { fewer( } 0.24 \\
\text { fewer to } 0.2 \text { more) }\end{array}$ \\
\hline $\begin{array}{l}\text { VAS score at } 24 \mathrm{~h} \text { after the onset } \\
\text { of analgesia }(\mathrm{mmol} / \mathrm{L})\end{array}$ & 33 (I RCT) & $\operatorname{LOW}^{1,5}$ & - & & $\begin{array}{l}\text { MD } 0.05 \text { fewer }(0.39 \\
\text { fewer to } 0.29 \text { more })\end{array}$ \\
\hline $\begin{array}{l}\text { VAS score at } 36 \mathrm{~h} \text { after the onset } \\
\text { of analgesia }(\mathrm{mmol} / \mathrm{L})\end{array}$ & 33 (I RCT) & LOW $^{1,5}$ & - & & $\begin{array}{l}\text { MD } 0.04 \text { fewer( } 0.35 \\
\text { fewer to } 0.27 \text { more) }\end{array}$ \\
\hline $\begin{array}{l}\text { Satisfaction rate of analgesic } \\
\text { effect }\end{array}$ & 33 (I RCT) & LOW $^{1,5}$ & $\begin{array}{l}\text { RR } 1.00(0.89 \\
\text { to } 1.12)\end{array}$ & 1,000 per 1,000 & $\begin{array}{l}0 \text { fewer per } 1,000(110 \\
\text { fewer to } 120 \text { more })\end{array}$ \\
\hline
\end{tabular}

(Continued) 
Appendix 2. (Continued).

\begin{tabular}{|c|c|c|c|c|c|}
\hline \multirow[t]{2}{*}{ Outcomes } & \multirow{2}{*}{$\begin{array}{l}\text { No of partici- } \\
\text { pants(studies) } \\
\text { Follow-up }\end{array}$} & \multirow{2}{*}{$\begin{array}{l}\text { Quality of the } \\
\text { evidence } \\
\text { (GRADE) }\end{array}$} & \multirow{2}{*}{$\begin{array}{l}\text { Relative } \\
\text { effect } \\
(95 \% \mathrm{CI})\end{array}$} & \multicolumn{2}{|l|}{$\begin{array}{l}\text { Anticipated } \\
\text { absolute effects }\end{array}$} \\
\hline & & & & $\begin{array}{l}\text { Risk with } \\
\text { control group }\end{array}$ & $\begin{array}{l}\text { Risk difference } \\
\text { with observation } \\
\text { group }\end{array}$ \\
\hline $\begin{array}{l}\text { Vausea and vomiting } \\
\text { Uroschesis }\end{array}$ & $\begin{array}{l}33 \text { (I RCT) } \\
33(\text { I RCT) }\end{array}$ & $\begin{array}{l}\text { LOW }^{1,5} \\
\text { LOW }^{1,5}\end{array}$ & $\begin{array}{l}\operatorname{RR} 0.31(0.01 \\
\text { to } 7.21) \\
\operatorname{RR~} 2.83(0.12 \\
\text { to } 64.89)\end{array}$ & 63 per 1,000 & $\begin{array}{l}43 \text { fewer per } 1,000(62 \\
\text { fewer to } 388 \text { more) } \\
\text { - }\end{array}$ \\
\hline \multicolumn{6}{|c|}{ Postoperative wound care: microwave treatment of VS routine care } \\
\hline Wound healing rate at first stage & I40 (I RCT) & $\operatorname{LOW}^{1,2}$ & $\begin{array}{l}\operatorname{RR} I .15(1.03 \\
\text { to } 1.29)\end{array}$ & 843 per 1,000 & $\begin{array}{l}126 \text { more per } I, 000 \\
(25 \text { more to } 244 \\
\text { more) }\end{array}$ \\
\hline \multicolumn{6}{|c|}{ Psychological intervention (including music therapy) VS routine care } \\
\hline $\begin{array}{l}\text { Systolic pressure immediately } \\
\text { into the operating room } \\
(\mathrm{mmHg})\end{array}$ & $200($ ( RCT) & LOW $^{2,6}$ & - & - & $\begin{array}{l}\text { MD } 9.8 \text { fewer( } 12.42 \\
\text { fewer to } 7.18 \text { fewer) }\end{array}$ \\
\hline $\begin{array}{l}\text { Systolic pressure after surgery } \\
\text { into the operating room } 30 \mathrm{~min} \\
(\mathrm{mmHg})\end{array}$ & 200 (I RCT) & LOW $^{2,6}$ & - & - & $\begin{array}{l}\text { MD } 35.37 \text { fewer } \\
\text { (38.32 fewer to } \\
32.42 \text { fewer) }\end{array}$ \\
\hline $\begin{array}{l}\text { Intraoperative systolic pressure } \\
(\mathrm{mmHg})\end{array}$ & 153 (I RCT) & $\operatorname{LOW}^{2,6}$ & - & - & $\begin{array}{l}\text { MD } 22.63 \text { fewer } \\
\text { (27.24 fewer to } \\
\text { 18.02 fewer) }\end{array}$ \\
\hline $\begin{array}{l}\text { Diastolic pressure immediately } \\
\text { into the operating room } \\
(\mathrm{mmHg})\end{array}$ & 200 (I RCT) & LOW $^{2,6}$ & - & - & $\begin{array}{l}\text { MD } 3.58 \text { fewer( } 5.2 \\
\text { fewer to } 1.96 \text { fewer) }\end{array}$ \\
\hline $\begin{array}{l}\text { Diastolic pressure after surgery } \\
\text { into the operating room } 30 \mathrm{~min} \\
(\mathrm{mmHg})\end{array}$ & 200 (I RCT) & $\operatorname{LOW}^{2,6}$ & - & - & $\begin{array}{l}\text { MD } 7.58 \text { fewer(9.62 } \\
\text { fewer to } 5.54 \text { fewer) }\end{array}$ \\
\hline $\begin{array}{l}\text { Intraoperative diastolic pressure } \\
(\mathrm{mmHg})\end{array}$ & $153($ I RCT) & $\operatorname{LOW}^{2,6}$ & - & - & $\begin{array}{l}\text { MD I0.6I fewer } \\
\text { (14.65 fewer to } 6.57 \\
\text { fewer) }\end{array}$ \\
\hline $\begin{array}{l}\text { Heart rate immediately into the } \\
\text { operating room }\end{array}$ & 200 (I RCT) & $\operatorname{LOW}^{5,6}$ & - & - & $\begin{array}{l}\text { MD } 0.86 \text { fewer( } 2.69 \\
\text { fewer to } 0.97 \text { more })\end{array}$ \\
\hline $\begin{array}{l}\text { Heart rate after surgery into the } \\
\text { operating room } 30 \mathrm{~min}\end{array}$ & 200 (I RCT) & $\operatorname{LOW}^{2,6}$ & - & - & $\begin{array}{l}\text { MD } 8.89 \text { fewer } \\
\text { (10.52 fewer to } 7.26 \\
\text { fewer) }\end{array}$ \\
\hline $\begin{array}{l}\text { Anxiety score immediately into } \\
\text { the operating room }\end{array}$ & 200 (I RCT) & $\operatorname{LOW}^{5,6}$ & - & - & $\begin{array}{l}\text { MD } 0.13 \text { fewer( } 2.57 \\
\text { fewer to } 2.31 \text { more })\end{array}$ \\
\hline $\begin{array}{l}\text { Anxiety score after surgery into } \\
\text { the operating room } 30 \mathrm{~min}\end{array}$ & $200($ I RCT) & LOW $^{2,6}$ & - & - & $\begin{array}{l}\text { MD } 2.22 \text { fewer(3.55 } \\
\text { fewer to } 0.89 \text { fewer) }\end{array}$ \\
\hline Intro-operative hemorrhage $(\mathrm{ml})$ & I53 (I RCT) & LOW $^{2,6}$ & - & - & $\begin{array}{l}\text { MD } 62.39 \text { fewer } \\
(78.31 \text { fewer to } \\
46.47 \text { fewer) }\end{array}$ \\
\hline Postoperative pains & $153($ I RCT) & $\operatorname{LOW}^{2,6}$ & $\begin{array}{l}\text { RR } 0.73(0.60 \\
\text { to } 0.89)\end{array}$ & 855 per 1,000 & $\begin{array}{l}231 \text { fewer per } 1,000 \\
\text { (342 fewer to } 94 \\
\text { fewer) }\end{array}$ \\
\hline
\end{tabular}

(Continued) 
Appendix 2. (Continued).

\begin{tabular}{|c|c|c|c|c|c|}
\hline \multirow[t]{2}{*}{ Outcomes } & \multirow{2}{*}{$\begin{array}{l}\text { No of partici- } \\
\text { pants(studies) } \\
\text { Follow-up }\end{array}$} & \multirow{2}{*}{$\begin{array}{l}\text { Quality of the } \\
\text { evidence } \\
\text { (GRADE) }\end{array}$} & \multirow{2}{*}{$\begin{array}{l}\text { Relative } \\
\text { effect } \\
(95 \% \mathrm{CI})\end{array}$} & \multicolumn{2}{|c|}{$\begin{array}{l}\text { Anticipated } \\
\text { absolute effects }\end{array}$} \\
\hline & & & & $\begin{array}{l}\text { Risk with } \\
\text { control group }\end{array}$ & $\begin{array}{l}\text { Risk difference } \\
\text { with observation } \\
\text { group }\end{array}$ \\
\hline Postoperative normal feeding & $153($ I RCT) & $\operatorname{LOW}^{5,6}$ & $\begin{array}{l}\text { RR } 1.07(0.99 \\
\text { to } 1.16)\end{array}$ & 908 per 1,000 & $\begin{array}{l}64 \text { more per } 1,000(9 \\
\text { fewer to } 145 \text { more) }\end{array}$ \\
\hline Postoperative morbidity & I53 (I RCT) & $\operatorname{LOW}^{2,6}$ & $\begin{array}{l}\operatorname{RR} 0.35(0.19 \\
\text { to } 0.64)\end{array}$ & 408 per 1,000 & $\begin{array}{l}265 \text { fewer per } 1,000 \\
(330 \text { fewer to } 147 \\
\text { fewer) }\end{array}$ \\
\hline \multicolumn{6}{|c|}{ Epidural anesthesia vs general anesthesia } \\
\hline $\begin{array}{l}\text { Blood glucose while skin cutting } \\
(\mathrm{mmol} / \mathrm{L})\end{array}$ & 54 (I RCT) & LOW $^{1,2}$ & - & - & $\begin{array}{l}\text { MD I.48 higher } \\
\text { (I.3I higher to } 1.56 \\
\text { higher) }\end{array}$ \\
\hline $\begin{array}{l}\text { Blood glucose while delivery of } \\
\text { the fetus (mmol/L) }\end{array}$ & 54 (I RCT) & LOW $^{1,5}$ & - & - & $\begin{array}{l}\text { MD } 0 \text { ( } 0.17 \text { lower to } \\
0.17 \text { higher })\end{array}$ \\
\hline $\begin{array}{l}\text { Blood glucose while delivery of } \\
\text { placenta(mmol/L) }\end{array}$ & 54 (I RCT) & LOW $^{1,2}$ & 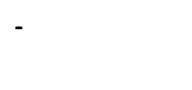 & - & $\begin{array}{l}\text { MD } 0.19 \text { fewer( } 0.37 \\
\text { fewer to } 0.1 \text { fewer })\end{array}$ \\
\hline $\begin{array}{l}\text { Blood glucose about } 2 \text { hours after } \\
\text { delivery of the fetus ( } \mathrm{mmol} / \mathrm{L})\end{array}$ & 54 (I RCT) & $\operatorname{LOW}^{1,2}$ & 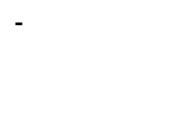 & - & $\begin{array}{l}\text { MD } 0.9 \text { higher( } 0.7 \text { I } \\
\text { higher to } 1.09 \\
\text { higher) }\end{array}$ \\
\hline $\begin{array}{l}\text { Blood glucose about } 6 \text { hours after } \\
\text { delivery of the fetus ( } \mathrm{mmol} / \mathrm{L})\end{array}$ & 54 (I RCT) & $\operatorname{LOW}^{1,2}$ & 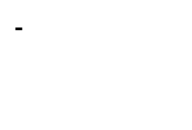 & - & $\begin{array}{l}\text { MD I.II higher } \\
\text { (0.93 higher to } 1.29 \\
\text { higher) }\end{array}$ \\
\hline Apgar scores $<7$ & $54($ ( RCT) & LOW ${ }^{1,5}$ & $\begin{array}{l}\text { RR } 0.20(0.01 \\
\text { to } 3.98)\end{array}$ & - & - \\
\hline \multicolumn{6}{|c|}{ Combined spinal and epidural analgesia: low dose sufentanil combined with bupivacaine VS bupivacaine } \\
\hline $\begin{array}{l}\text { Blood glucose while skin cutting } \\
(\mathrm{mmol} / \mathrm{L})\end{array}$ & 66 (I RCT) & $\operatorname{LOW}^{1,2}$ & - & - & $\begin{array}{l}\text { MD I.45 fewer(I.6I } \\
\text { fewer to I.29 fewer) }\end{array}$ \\
\hline $\begin{array}{l}\text { Blood glucose while delivery of } \\
\text { the fetus (mmol/L) }\end{array}$ & 66 (I RCT) & LOW $^{1,5}$ & - & - & $\begin{array}{l}\text { MD } 0.01 \text { more }(0.13 \\
\text { fewer to } 0.15 \text { more })\end{array}$ \\
\hline $\begin{array}{l}\text { Blood glucose about } 5 \mathrm{~min} \text { after } \\
\text { delivery of placenta }(\mathrm{mmol} / \mathrm{L})\end{array}$ & 66 (I RCT) & $\operatorname{LOW}^{1,2}$ & - & - & $\begin{array}{l}\text { MD } 0.23 \text { more }(0.06 \\
\text { more to } 0.4 \text { more })\end{array}$ \\
\hline $\begin{array}{l}\text { Blood glucose about } 2 \text { hours } \\
\text { after delivery of the fetus } \\
(\mathrm{mmol} / \mathrm{L})\end{array}$ & 66 (I RCT) & LOW $^{1,2}$ & - & - & $\begin{array}{l}\text { MD } 0.89 \text { fewer( } 1.07 \\
\text { fewer to } 0.7 \text { I fewer) }\end{array}$ \\
\hline $\begin{array}{l}\text { Mean arterial pressure at Imin } \\
\text { after anesthesia }(\mathrm{mmHg})\end{array}$ & 66 (I RCT) & $\operatorname{LOW}^{1,5}$ & - & - & $\begin{array}{l}\text { MD } 0.4 \text { more( } 2.11 \\
\text { fewer to } 2.91 \text { more) }\end{array}$ \\
\hline $\begin{array}{l}\text { Mean arterial pressure at } 2 \mathrm{~min} \\
\text { after anesthesia }(\mathrm{mmHg})\end{array}$ & 66 (I RCT) & LOW ${ }^{1,5}$ & - & - & $\begin{array}{l}\text { MD I.4 more(I.62 } \\
\text { fewer to } 4.42 \text { more) }\end{array}$ \\
\hline $\begin{array}{l}\text { Mean arterial pressure at } 5 \mathrm{~min} \\
\text { after anesthesia }(\mathrm{mmHg})\end{array}$ & 66 (I RCT) & $\operatorname{LOW}^{1,2}$ & - & - & $\begin{array}{l}\text { MD } 5.8 \text { more( } 3.12 \\
\text { more to } 8.48 \text { more) }\end{array}$ \\
\hline $\begin{array}{l}\text { Mean arterial pressure at } 10 \mathrm{~min} \\
\text { after anesthesia }(\mathrm{mmHg}) \\
\text { Mean arterial pressure at } 20 \mathrm{~min} \\
\text { after anesthesia }(\mathrm{mmHg})\end{array}$ & $\begin{array}{l}66 \text { (I RCT) } \\
66 \text { (I RCT) }\end{array}$ & $\begin{array}{l}\operatorname{LOW}^{1,5} \\
\operatorname{LOW}^{1,5}\end{array}$ & - & - & $\begin{array}{l}\text { MD } 0.3 \text { more( } 2.47 \\
\text { fewer to } 3.07 \text { more) } \\
\text { MD } 1.9 \text { more(I.I } \\
\text { fewer to } 4.9 \text { more) }\end{array}$ \\
\hline
\end{tabular}

(Continued) 
Appendix 2. (Continued).

\begin{tabular}{|c|c|c|c|c|c|}
\hline \multirow[t]{2}{*}{ Outcomes } & \multirow{2}{*}{$\begin{array}{l}\text { No of partici- } \\
\text { pants(studies) } \\
\text { Follow-up }\end{array}$} & \multirow{2}{*}{$\begin{array}{l}\text { Quality of the } \\
\text { evidence } \\
\text { (GRADE) }\end{array}$} & \multirow{2}{*}{$\begin{array}{l}\text { Relative } \\
\text { effect } \\
(95 \% \mathrm{Cl})\end{array}$} & \multicolumn{2}{|l|}{$\begin{array}{l}\text { Anticipated } \\
\text { absolute effects }\end{array}$} \\
\hline & & & & $\begin{array}{l}\text { Risk with } \\
\text { control group }\end{array}$ & $\begin{array}{l}\text { Risk difference } \\
\text { with observation } \\
\text { group }\end{array}$ \\
\hline Apgar score at $5 \mathrm{mins}$ & $\begin{array}{l}66 \text { (I RCT) } \\
66 \text { (I RCT) }\end{array}$ & $\begin{array}{l}\text { LOW }^{1,5} \\
\text { LOW }^{1,2}\end{array}$ & - & - & $\begin{array}{l}\text { MD } 0.1 \text { more }(0.17 \\
\text { fewer to } 0.37 \text { more }) \\
\text { MD } 0.1 \text { more( } \mathbf{0 . 0 2} \\
\text { more to } \mathbf{0 . 1 8} \text { more) }\end{array}$ \\
\hline \multicolumn{6}{|c|}{ Additional an antibiotic once vs 24 hours antibiotic application } \\
\hline Marked effective rate & 120 (I RCT) & $\operatorname{LOW}^{1,2}$ & $\begin{array}{l}R R 0.68(0.48 \\
\text { to } 0.97)\end{array}$ & 633 per 1,000 & $\begin{array}{l}203 \text { fewer per } 1,000 \\
\text { (329 fewer to } 19 \\
\text { fewer) }\end{array}$ \\
\hline Effective rate & 120 (I RCT) & LOW ${ }^{1,5}$ & $\begin{array}{l}\text { RR I.50(0.97 } \\
\text { to } 2.33)\end{array}$ & 333 per 1,000 & $\begin{array}{l}167 \text { more per } 1,000(10 \\
\text { fewer to } 443 \text { more) }\end{array}$ \\
\hline Inefficient rate & I20 (I RCT) & LOW ${ }^{1,5}$ & $\begin{array}{l}\text { RR } 2.00(0.38 \\
\text { to } 10.51)\end{array}$ & 33 per 1,000 & $\begin{array}{l}33 \text { more per } 1,000(21 \\
\text { fewer to } 317 \text { more) }\end{array}$ \\
\hline Total effective rate & 120 (I RCT) & $\operatorname{LOW}^{1,5}$ & $\begin{array}{l}\text { RR } 0.97(0.89 \\
\text { to } 1.05)\end{array}$ & 967 per 1,000 & $\begin{array}{l}29 \text { fewer per } 1,000 \\
\text { (106 fewer to } 48 \\
\text { more) }\end{array}$ \\
\hline WBC $<12 \times 10^{9} / \mathrm{L}$ time $(\mathrm{d})$ & I20 (I RCT) & $\operatorname{LOW}^{1,5}$ & - & - & $\begin{array}{l}\text { MD } 0.50 \text { more }(0.02 \\
\text { fewer to } 1.02 \text { more })\end{array}$ \\
\hline $\begin{array}{l}\text { Body temperature (no fever and } \\
\text { return to normal } 48 \mathrm{~h} \text { after } \\
\text { surgery) }\end{array}$ & I20 (I RCT) & $\operatorname{LOW}^{1,5}$ & $\begin{array}{l}\operatorname{RR} 0.98(0.93 \\
\text { to } 1.04)\end{array}$ & 983 per 1,000 & $\begin{array}{l}20 \text { fewer per } 1,000(69 \\
\text { fewer to } 39 \text { more })\end{array}$ \\
\hline Class-A healing rate & 120 (I RCT) & LOW ${ }^{1,5}$ & $\begin{array}{l}\mathrm{RR} 0.97(0.89 \\
\text { to } 1.05)\end{array}$ & 967 per 1,000 & $\begin{array}{l}29 \text { fewer per } 1,000 \\
\text { (106 fewer to } 48 \\
\text { more) }\end{array}$ \\
\hline Class- $B$ healing rate & I 20 (I RCT) & $\operatorname{LOW}^{1,5}$ & $\begin{array}{l}\text { RR } 2.00(0.38 \\
\text { to } 10.51)\end{array}$ & 33 per 1,000 & $\begin{array}{l}33 \text { more per } 1,000(21 \\
\text { fewer to } 317 \text { more) }\end{array}$ \\
\hline Class- $C$ healing rate & I 20 (I RCT) & - & & - & \\
\hline \multicolumn{6}{|c|}{$\begin{array}{l}\text { *The risk in the intervention group (and its } 95 \% \mathrm{Cl} \text { ) is based on the assumed risk in the comparison group and the relative effect of the intervention (and its } 95 \% \\
\text { CI). } \\
\text { GRADE Working Group grades of evidence: high quality: we are very confident that the true effect lies close to that of the estimate of the effect. } \\
\text { Moderate quality: we are moderately confident in the effect estimate: The true effect is likely to be close to the estimate of the effect, but there is a possibility } \\
\text { that it is substantially different. Low quality: our confidence in the effect estimate is limited: The true effect may be substantially different from the estimate of } \\
\text { the effect. Very low quality: we have very little confidence in the effect estimate: The true effect is likely to be substantially different from the estimate of effect }\end{array}$} \\
\hline
\end{tabular}

Notes: 'No random sequences were reported to generate and assign hidden methods, and no blindness was given to researchers, subjects, and outcome evaluators. ${ }^{2}$ The sample size is less than the optimal information sample size. ${ }^{3}$ None of the studies reported randomized generation and allocation of hidden methods, one of which did not blind the researchers and subjects. ${ }^{4}$ The method of generating and assigning hidden random numbers is not reported. ${ }^{5}$ The sample size is less than the optimal information sample size, and the confidence interval of the combined effect is across the invalid line. ${ }^{6} \mathrm{No}$ evaluation of the outcome of the blind. The bold values mean the effect or difference was statistically significant.

Abbreviation: MD, mean difference.

Diabetes, Metabolic Syndrome and Obesity: Targets and Therapy

\section{Dovepress}

\section{Publish your work in this journal}

Diabetes, Metabolic Syndrome and Obesity: Targets and Therapy is an international, peer-reviewed open-access journal committed to the rapid publication of the latest laboratory and clinical findings in the fields of diabetes, metabolic syndrome and obesity research. Original research, review, case reports, hypothesis formation, expert opinion and commentaries are all considered for publication. The manuscript management system is completely online and includes a very quick and fair peer-review system, which is all easy to use. Visit http://www.dovepress.com/testimonials.php to read real quotes from published authors. 